\title{
NEW BOOKS RECEIVED
}

The Astronomers' Universe, by Bart J. Bok, published by New York: Cambridge University Press, 32 East 57th St., New York 22, N. Y. Price \$3.75.

The Threshold of Space, edited by M. Zelikoff, published by Pergamon Press Inc., 122 East 55th St., New York 22, N. Y. Price \$15.00.

L'Exploration des Galaxies Voisines, par les méthodes optiques et radio-électriques, by Gérard de Vaucouleurs, published by Masson et C ${ }^{\text {ie }}$ Ed., Paris, France. Price 1.600 fr.

\section{NOTICES}

The American Institute of Physics has undertaken the complete translation of all issues of the "Astronomical Journal of the Academy of Sciences of the USSR," commencing with the 1957 issues. As the title suggests, this journal covers various problems in astronomy, including solar activity, stellar studies, spectroscopic investigations and radio astronomy.

There are six issues annually; subscription price: $\$ 25.00$ domestic, $\$ 27.00$ foreign $(\$ 10.00$ and $\$ 12.00$ respectively for libraries of nonprofit degree-granting institutions). Subscriptions and inquiries should be addressed to: Translation Journals-American Institute of Physics, 335 East 45 Street, New York 17, N. Y.

A Symposium on Boundary Problems in Differential Equations, with special reference to recent developments in this field, will be held by the Mathematics Research Center, United States Army, at the University of Wisconsin April 20-22, 1959. Invited speakers, about twenty in number, will each present a thirty-minute paper. Both ordinary and partial differential equations will be considered, the emphasis to be upon methods that are potentially adapted to computation. Between lectures there will be discussion periods and coffee breaks. The proceedings of the Symposium will be published.

Among the speakers, European and American, will be
L. Collatz
R. Bellman
K. Friedrichs
G. Fichera
G. Birkhoff
P. Garabedian
L. Fox
H. Bueckner
B. A. Troesch
W. T. Koiter
R. Courant
R. Varga
J. Schröder
J. B. Diaz
C. Wilcox
I. N. Sneddon
J. Douglas
D. Young

Persons interested in attending the symposium may receive the program and other details by writing to

\author{
R. E. Langer, Director \\ Mathematics Research Center, U. S. Army \\ 1118 West Johnson Street \\ Madison 6, Wisconsin
}

